\title{
Chemical Composition, Antioxidant and Antibacterial Properties of Chloroform Fraction of Platycerium Bifurcatum
}

\author{
Ikpa Chinyere Benardette Chinaka ${ }^{1}$, Onoja Samuel Okwudili", \\ Dozie-Akaniro ljeoma Nkiru ${ }^{3}$
}

\author{
${ }^{1}$ Departement of Chemistry, Imo State University P.M.B 2000, Owerri, Imo State Nigeria \\ ${ }^{2}$ Department of Veterinary Physiology and Pharmacology, College of Veterinary Medicine, Michael Okpara \\ University of Agriculture Umudike, PMB 7267, Umuahia Abia State Nigeria \\ ${ }^{3}$ Departement of Plants Science and Biotechnology. Imo State University P.M.B 2000, Owerri, Imo State
} Nigeria

\begin{abstract}
The study investigated the bioactive constituents, antioxidant and antibacterial activities of Platycerium bifucartum leaves. Chloroform fraction of $P$. bifurcatum was prepared by partitioning the ethanol extract with chloroform and water. The phytochemical analysis was carried out using standard methods. Fourier transformer-infrared (FT-IR) and Gas chromatography-mass spectroscopy (GC/MS) were used in the characterization of the bioactive compounds. The antioxidant and antibacterial activities of the chloroform fraction were evaluated using standard protocols. The fourier transformer-infrared analysis showed the presence of $\mathrm{C}=\mathrm{O}, \mathrm{OH}, \mathrm{CHO}, \mathrm{C}-\mathrm{F}$ and $-\mathrm{NH}$ functional groups. GC/MS characterization gave benzeneethaneamine (33.3\%), 2-amino-1-(4-methylphenyl) propane (17.04\%), hydroxyurea $(30.26 \%)$ and epinephrine (13.26). The extract inhibited the growth of the bacterial isolates. The fraction exhibited antioxidant properties that were comparable with ascorbic acid. The presence of these compounds showed that the leaves of Platycerium bifurcatum can be used for the treatment of some bacterial diseases.
\end{abstract}

Key words: Benzeneethaneamine, Epinephrine, Hydroxyurea, Natural Product, Poplypodiaceae.

\section{Introduction}

Platycerium bifurcatum belongs to the family of Poplypodiaceae and its common names (English) include "elkhorn fern" or "staghorn fern" $[1,2]$. Platycerium bifurcatum is called "akpaka iyi" in Igbo language (especially by the natives of Owerri, Imo State Nigeria). Some species of the genus Platycerium like $P$. bifurcatum and $P$. superbum are commonly cultivated around homes and offices as ornamental plants. They grow on trees, rocks and gardens in tropical region. In Imo state Nigeria, the leaves of $P$. bifurcatum is used in traditional treatment of fever, premature

\footnotetext{
* Corresponding author: Onoja Samuel Okwudili, Onoja.samuel@mouau.edu.ng
}

(cc) BY-NC-ND 2018 Ikpa Chinyere Benardette Chinaka et al., published by This work was licensed under the Creative Commons Attribution-NonCommercialNoDerivs 3.0 License abortion, irregular menstruation, inflammation and ulcer (oral communication). The leaves of $P$. bifurcatum are used in ethnomedical treatment of ulcer, miscarriages in women, oedema, cough and hypertension treatment [1]. The antibacterial activity of $P$. bifurcatum has been reported by previous investigators [3]. The chemical constituents responsible for these biological activities of Platycerium bifurcatum are yet to be established. This study investigated the bioactive constituents, antioxidant and antibacterial activities of the leaves of Platycerium bifurcatum.

\section{Material and Methods}

Identification and preparation of extract. The leaves of $P$. bifurcatum was identified by Dr. F. N. Mbagwu. The leaves were harvested from an oil bean tree in the University premises. The leaves samples were dried at room temperature and grinded with mortar and pestle into coarse 
powder. Three hundred gramme (300 gramme) of the ground sample was soaked in $1.5 \mathrm{~L}$ of ethanol for $48 \mathrm{~h}$. The extract was filtered with Whatman No: 1 filter paper and concentrated with hot air oven. The crude ethanolic extract was partitioned with water and chloroform with the aid of a separating funnel. The chloroform fraction was concentrated in hot air oven and was used for the studies.

Fourier transformer infrared (FT-IR) spectroscopy. The chloroform fraction (1 $\mathrm{mg})$ were mixed with potassium bromide $(\mathrm{KBr})$, pulverized, and formed into a disk-shaped pellet. The spectra were recorded in the frequency region $500-4000 \mathrm{~cm}$ 1 , under a resolution of $2 \mathrm{~cm}-1$ and with a scanning speed of $2 \mathrm{~mm} \mathrm{sec}-1$ with Shimadzu FTIR 8400s fourier transformer infrared.

Gas chromatography-mass spectra (GC-MS) Analysis. Analysis was conducted using GC-MS (Agilent 7890A) equipped with a DB-5MS column ( $30 \mathrm{~m} \times 0.25 \mathrm{~mm}$ i.d., 0.25 um film thickness, J \& W Scientific, Folsom, CA). The initial oven temperature was $60{ }^{\circ} \mathrm{C}$. Helium was used as the carrier gas at the rate of $1.0 \mathrm{~mL} / \mathrm{min}$. The eluent of the GC column was introduced directly into the source of the MS via a transfer line $\left(250{ }^{\circ} \mathrm{C}\right)$. lonization voltage was $70 \mathrm{eV}$ and ion source temperature was $230{ }^{\circ} \mathrm{C}$. Scan range was $41-450$ amu. The components were identified by comparing their retention times to the reference in the national institute of standards and technology (NIST, ver. 2.0, 2008) mass spectral database.

Antibacterial activity

Antibacterial sensitivity test. Agar well diffusion technique as described by Paliwal et al. [4] was used to determine the antibacterial activity of the chloroform fraction against Escherichia coli, Staphylococcus aureus, Pseudomonas aeruginosa and Klebsiella pneumonia. Ciprofloxacin was used as reference standard and the zones of inhibition were measured with metre rule to the nearest millimetre.

Minimum inhibitory concentration (MIC). Broth dilution technique was used in the evaluation of the MIC of $P$. bifurcatum [5]. Each of the organism was incubated with the extract at 10.0 to 200 $\mu \mathrm{g} / \mathrm{mL}$ concentration.

Antioxidant activity

2, 2-diphenyl-1-picrylhydrazyl (DPPH) scavenging Assay. The DPPH (Sigma Aldrich, USA) scavenging property of $P$. bifurcatum was evaluated as modified by Ezeja et al. [6] at 25 $400 \mu \mathrm{g} / \mathrm{mL}$ concentrations in triplicate and ascorbic acid was used as standard.

Ferric reducing antioxidant power (FRAP). The FRAP of $P$. bifurcatum was evaluated as modified by Onoja et al. [7]. The FRAP of $P$. bifurcatum at $25-400 \mu \mathrm{g} / \mathrm{mL}$ concentrations were determined in triplicate.

Statistical analysis. Data were analyzed with statistical package of social science (SPSS) version 20 using one way analysis of variance (ANOVA). Least Significant Difference (LSD) was used to separate mean difference and significance was accepted at the level of $p<0.05$.

\section{Results and Discussions}

FT-IR analysis of the chloroform fraction of $P$. bifurcatum leaves showed the presence of the following functional groups; $\mathrm{R}-\mathrm{OR}, \mathrm{R}-\mathrm{F}, \mathrm{C}=\mathrm{O}$, and $-\mathrm{OH}$ and two stretching (Table 1).

Table 1

Results FT-IR Analysis of $\boldsymbol{P}$. bifurcatum Leaves

\begin{tabular}{clcl}
\hline S/N & $\begin{array}{c}\text { Functional } \\
\text { groups }\end{array}$ & Peaks & Comments \\
\hline 1 & R-OR & 1072.46 & Stretching \\
2 & R-F & 1178.55 & Stretching \\
3 & C=O & 1721.53 & Aldehyde \\
4 & $-\mathrm{NH}-$ & 3416.05 & $2^{\mathrm{U}}$ amine \\
5 & $-\mathrm{OH}-$ & 3735.28 & Phenol \\
\hline
\end{tabular}

The GC/MS identified the presence of four bioactive compounds; Benzeneethamine (33.3\%), 2-amino-1-(4-methylphenyl) propane (17.04\%), Hydroxyurea (30.26\%) and Epinephrine (13.63\%) (Table 2 and Figure 1).

Table 2

Result of GC-MS Analysis

\begin{tabular}{lllllc}
\hline & Compound Name & Molecular weight & \multicolumn{1}{c}{ Molecular formula } & ID & \% content \\
\hline $\mathbf{1}$ & Benzeneethanamine & 185 & $\mathrm{C}_{9} \mathrm{H}_{12} \mathrm{FNO}_{2}$ & 14308 & 33.30 \\
$\mathbf{2}$ & 4-methylamphetamine & 149 & $\mathrm{C}_{10} \mathrm{H}_{15} \mathrm{~N}$ & 3385 & 17.04 \\
$\mathbf{3}$ & Hydroxyurea & 76 & $\mathrm{C}_{4} \mathrm{~N}_{2} \mathrm{O}_{2}$ & 3413 & 30.26 \\
$\mathbf{4}$ & Epinephrine & 183 & $\mathrm{C}_{9} \mathrm{H}_{13} \mathrm{NO}_{3}$ & 3438 & 13.63 \\
\hline ID=Retention index, \% content=Percentage content. & & &
\end{tabular}


<smiles>CNCC(O)c1cc(O)cc(F)c1</smiles>

Benzeneethanamine<smiles>NC(=O)NO</smiles>

Hydroxyurea<smiles>Cc1ccc(CC(C)N)cc1</smiles>

4-Methylamphetamine<smiles>CNCC(O)c1ccc(O)c(O)c1</smiles>

Fig. 1. Structure of identified compounds

The extract produced concentration dependent increase in zone of growth inhibition against $S$. aureus, E. coli, $P$. aeruginosa and $K$. pneumonia
(Table 3) and the MIC of ranged from 25 - 100 $\mu \mathrm{g} / \mathrm{mL}$ which were higher when compared with ciprofloxacin (Table 4).

Table 3

Zone of growth inhibition on test organisms

\begin{tabular}{llllll}
\hline \multirow{2}{*}{ Vol. $(\boldsymbol{\mu l})$ of $\mathbf{1 0} \mathbf{~} \mathbf{~ g} \mathbf{~} \mathbf{m l}$} & \multicolumn{1}{c}{ Drugs } & S. aureus & E-coli & P. aeroginosa & K. pneumonia \\
\hline 400 & P. bifurcatum. & 17 & 18 & 17 & 22 \\
& Ciproflox. & 20 & 16 & 17 & 20 \\
300 & P. bifurcatum. & 16 & 16 & 15 & 20 \\
& Ciproflox. & 18 & 12 & 16 & 20 \\
200 & P. bifurcatum. & 13 & 12 & 13 & 16 \\
\multirow{2}{*}{100} & Ciproflox. & 17 & 15 & 15 & 18 \\
& P. bifurcatum. & - & 6 & - & 12 \\
& Ciprofloxacin. & 12 & 23 & 13 & 12 \\
\hline
\end{tabular}

Minimum inhibition concentration

Minimum inhibition concentration $(\mu \mathrm{g} / \mathrm{mL})$

\begin{tabular}{ccccc} 
Compound & S. aureus & E-coli & P. aeroginosa & K. pneumonia \\
\hline P. Bifurcatum & 100 & 50 & 100 & 25 \\
Ciprofloxacin & $>50$ & 25 & 50 & $>25$ \\
\hline
\end{tabular}


The extract at $200 \mu \mathrm{g} / \mathrm{mL}$ and $400 \mu \mathrm{g} / \mathrm{mL}$ concentrations, caused significant reduction of DPPH free radicals of 41.17 and $75.82 \%$ respectively. The IC50 of the extract is greater than $200 \mu \mathrm{g} / \mathrm{mL}$ and less than $400 \mu \mathrm{g} / \mathrm{mL}$ of the extract (Fig. 2). The extract produced its optimum effect $1.85 \mu \mathrm{M}$ at $400 \mu \mathrm{g} / \mathrm{mL}$ comparable to ascorbic acid at $125 \mu \mathrm{g} / \mathrm{mL}$ (Fig. 3).

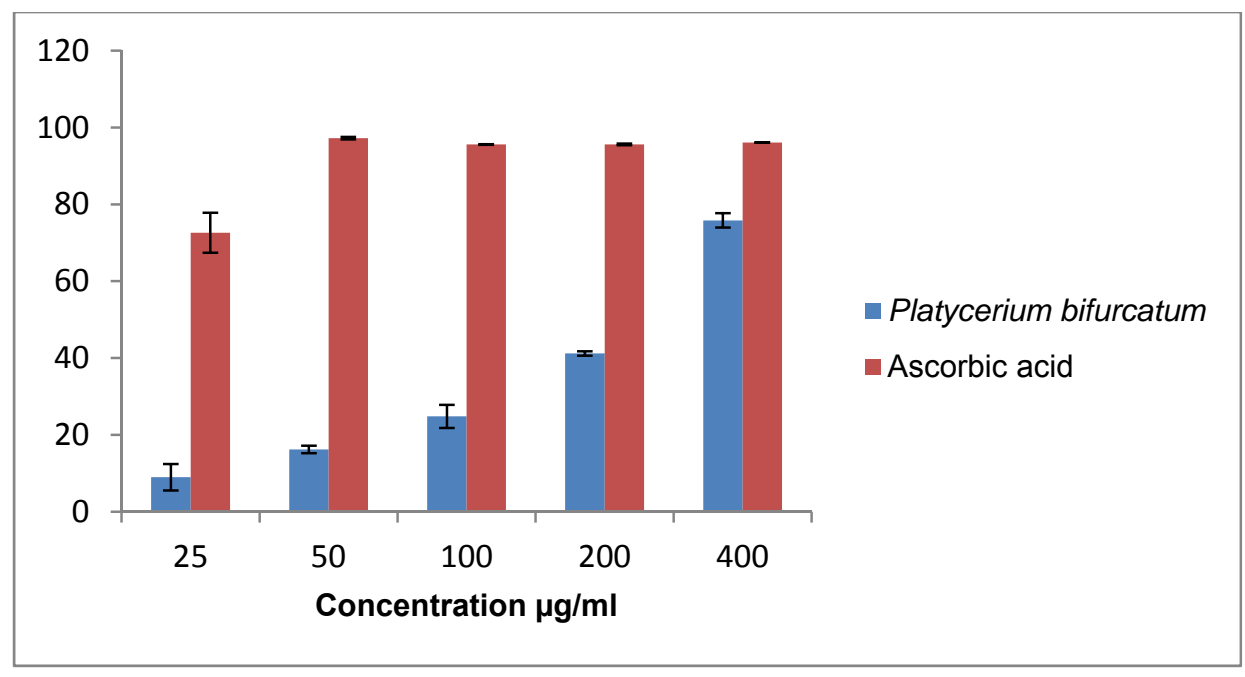

Fig. 2: DPPH radical scavenging activity of Platycerium bifurcatum

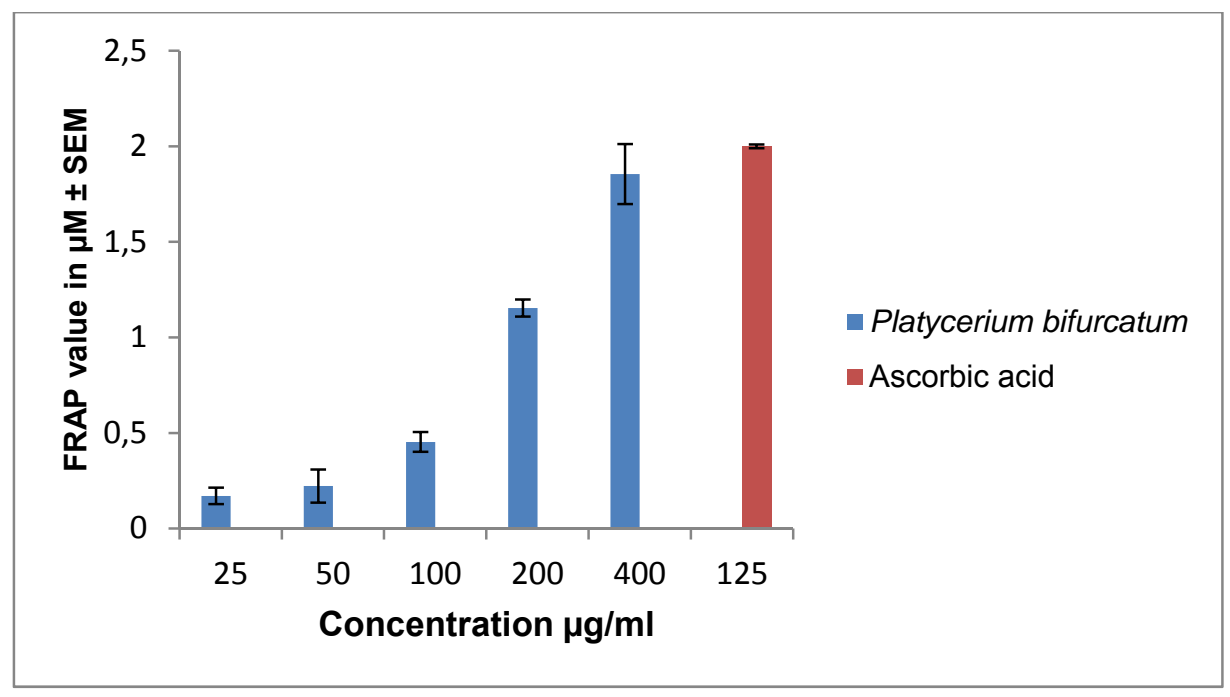

Fig. 3. The FRAP value of Platycerium bifurcatum

The antioxidant and antibacterial activities of $P$. bifurcatum can be linked to benzeneethanamine and hydroxyurea $[8,9]$. The antioxidant, antimicrobial and anti-inflammatory activities of benzeneethanamine have been reported $[9,10]$. Benzeneethanamine and its derivatives have been identified in several other medicinal plants such Azardirachta indica, Ocimum sanctum, Macrotyloma uniflorum and Canscora perfoliata [11-13]. 4-methyamphetamine, methylated derivative of amphetamine and epinephrine are sympathomimetic drugs that are used as central nervous system stimulant in anaphylactic shock, asthma, cardiac arrest, and as anorectic agent [14]. The major side-effect is hypertension [15]. This indicates that the plant can be used with caution in hypertensive patients [14,15]. The analgesic property of $P$. bifurcatum might be linked to epinephrine; pain neuron inhibitor [16]. Hydroxyurea is a hydroxylamine with many biological activities. The antioxidant, antibacterial, anti-sickle cell anaemia, and anticancer activities of hydroxyurea have been documented [8,17-20]. It is also used in the treatment of human 
immunodeficiency virus (HIV) [8]. Hydroxyurea has been identified in Arabidopsis, Cajanus cajan, Carica papaya and Zanthoxylum zanthoxyloides leaves [21-23]. The presence of hydroxyurea in $P$. bifurcatum suggests that it can be employed in the traditional treatment of sickle cell anaemia, human immunodeficiency virus (HIV) and cancer [19,21]. The demonstrated antibacterial property against both Gram negative and Gram positive isolates, suggests that the plant would be effective in the treatment of infection caused by some of these organism such as wound contamination and enteric diseases [8].

\section{Conclusions}

The study validates the folkloric uses of platycerium bifurcatum in the treatment of infectious diseases and provided the pharmacological basis for its medicinal values.

\section{Acknowledgements}

The author appreciates the contribution of Dr. F. $\mathrm{N}$. Mbagwu for the identification of the plant sample.

\section{References}

1. Agbo, M.O., Nnadi, C.O., Ukwueze, N.N., \& Okoye, F.B.C. (2014). Phenolic constituents from Platycerium bifurcatum and their antioxidatant properties. Journal of Natural Products, 7 , 48-57. http://www.journalofnaturalproducts.com/Volume7/7_Re s_paper-6.pdf

2. Holtum, J.A., \& Winter, K. (1999). Degrees of crassulacean acid metabolism in tropical epiphytic and lithophytic ferns. Functional Plant Biology, 26 (8), 749757. https://doi.org/10.1071/PP99001

3. Ojo, O.O., Ajayi, A.O., \& Anibijuwon, I.I. (2007). Antibacterial potency of methanol extracts of lower plants. Journal of Zheijang University Science B, 8 (3), 189-191. https://doi.org/10.1631/izus.2007.B0189 4. Paliwal, S.K., Sati, B., Faujdar, S., \& Sharma, S. (2017). Antioxidant and antibacterial activities of various extracts of Inula cuspidata CB Clarke stem. Beni-seuf University Journal of Applied Sciences, 6 (2), 97-105. https://doi.org/10.1016/j.bjbas.2016.10.003

5. Stalons, D.R., \& Thornsberry, C. (1975). Brothdilution method for determining the antibiotic susceptibility of anaerobic bacteria. Antimicrobial Agents Chemotherapy, $7 \quad$ (1), 15-21. http://aac.asm.org/content/7/1/15.full.pdf

6. Ezeja, M.I., Omeh, Y.N., Onoja, S.O., \& Ukaonu, I.H. (2015). Anti-inflammatory and antioxidant activities of the methanolic leaf extract of Cissus aralioides. American Journal of Pharmacological Sciences 3 (1), 1-6. DOI: 10.12691/ajps-3-1-1

7. Onoja, S.O., Ezeja, M.I., Omeh, Y.N., \& Onwukwe, B.C. (2016). Antioxidant, anti-inflammatory and antinociceptive activities of methanolic extract of Justicia secunda Vahl leaf. Alexandria Journal of

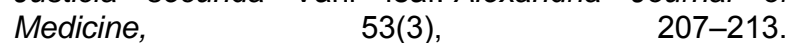
https://doi.org/10.1016/j.aime.2016.06.001
8. Kos, I., Jadrijević-Mladar, M., Butula, I., Biruš, M., Maravić-Vlahoviček, G., \& Dabelić, S. (2013). Synthesis, antibacterial and cytotoxic activity evaluation of hydroxyurea derivatives. Acta Pharmaceutica, 63 (2), 175-191. DOI: 10.2478/acph-2013-0014

9. Krishnanunni, K., Senthilvel, P., Ramaiah, S. \& Anbarasu, A. (2015). Study of chemical composition and volatile compounds along with in-vitro assay of antioxidant activity of two medicinal rice varieties: Karungkuravai and Mappilai samba. Journal of Food Science and Technology, 52(5), 2572-2584. doi: 10.1007/s13197-014-1292-z

10. Altaee, N., Kadhim, M.J., \& Hameed, I.H. (2016). Characterization of metabolites produced by E. Coli and analysis of its chemical compounds using GC-MS. International Journal of Current Pharmaceutical Review and Research. 7 (6), 393-399. www.ijcpr.com

11. Das, S., Vasudeva, N., \& Sharma, S. (2014). Chemical composition of ethanol extract of Macrotyloma uniflorum (Lam.) Verdc. using GC-MS spectroscopy. Organic and Medicinal Chemistry Letters, 4 (1),

13. https://doi.org/10.1186/s13588-014-0013-y

12. Harikrishnan, R., Kim, M.C., Kim, J.S., Balasundaram, C., Jawahar, S., \& Heo, M.S. (2010). Identification and antimicrobial activity of combined extract from Azadirachta indica and Ocimum Sanctum. Israeli journal of aquaculture = Bamidgeh, 62 (2), 2010, 85-95. http://hdl.handle.net/10524/19317

13. Thanga, K.K.S., Muthukumarasamy, S. \& Mohan, V.R. (2012). GC-MS determination of bioactive components of Canscora perfoliata Lam.(Gentianaceae). of Applied Pharmaceutical Science, 2 (8), 210-214. DOI: 10.7324/JAPS.2012.2837

14. Rang, H.P., Dale, M.M., Ritter, J.M., \& Moore, R.K. (2003). Pharmacology $5^{\text {th }}$ edition, Edinburgh, Churchill livingstone.

15. Kounis, N.G., Soufras, G.D., Lianas, D., \& Patsouras, N. (2016). After administration of intravenous epinephrine for bee sting-induced anaphylaxis: Kounis syndrome or epinephrine effect? Chinese Medical Journal, 129, 500-501. doi: 10.4103/0366-6999.176081

16. Bahmani, M., Shirzad, H., Majlesi, M., Shahinfard, N. \& Rafieian-Kopaei, M. (2014). A review study on analgesic applications of Iranian medicinal plants. Asian Pacific Journal of Tropical Medicine, 7, S43-S53. https://doi.org/10.1016/S1995-7645(14)60202-9

17. Hoffman, E.A., McCulley, A., Haarer, B., Arnak, R., \& Feng, W. (2015). Break-seq reveals hydroxyureainduced chromosome fragility as a result of unscheduled conflict between DNA replication and transcription. Genome Research, 25 (3), 402-412. doi/10.1101/gr.180497.114.

18. Julián, E., Baelo, A., Gavaldà, J., \& Torrents, E. (2015). Methyl-hydroxylamine as an efficacious antibacterial agent that targets the ribonucleotide reductase enzyme. PLoS ONE 10(3), e0122049. doi:10.1371/journal.pone.0122049

19. Platt, O.S. (2008). Hydroxyurea for the treatment of sickle cell anemia. New England Journal of Medicine, 358 (13), 1362-1369. DOI: 10.1056/NEJMct0708272 
20. Yuh-Hwa, L.I.U., Wen-Chun, W.U., Yeh-Lin, L.U., Ying-Jang, L.A.I., \& Wen-Chi, H.O.U. (2010). Antioxidant and amine oxidase inhibitory activities of hydroxyurea. Bioscience Biotechnology Biochemistry, 74 (6), 1256-1260. DOI: 10.1271/bbb.10009

21. Nurain, I.O., Bewaji, C.O., Johnson, J.S., Davenport, R.D., \& Zhang, Y., (2016). Potential of three ethnomedicinal plants as antisickling agents. Molecular pharmaceutics. 14(1), 172-182. DOI: 10.1021/acs.molpharmaceut.6b00767
22. Pecinka, A., \& Liu, C.H. (2014). Drugs for plant chromosome and chromatin research. Cytogenetic and Genome Research, $143 \quad$ (1-3), 51-59. https://doi.org/10.1159/000360774

23. Petersen, M., Hofius, D., \& Andersen, S.U. (2014). Signaling unmasked: autophagy and catalase promote programmed cell death. Autophagy. 10(3), 520-521. https://doi.org/10.4161/auto.27564 . 